\title{
A REVIEW OF THE FOREST MANAGEMENT HISTORY AND PRESENT STATE OF THE HARAGISTYA KARST PLATEAU (AGGTELEK KARST, HUNGARY)
}

\author{
PREGLED UPRAVLJANJA Z GOZDOVI NA PLANOTI \\ HARAGISTYA (AGGTELEŠKI KRAS, MADŽARSKA)
}

\author{
Eszter TANÁCS ${ }^{1}$, Ferenc SZMORAD², Ilona BÁRÁNY-KEVEI ${ }^{3}$
}

\begin{abstract}
UDC 551.44:630*6(439)

Eszter Tanács, Ferenc Szmorad, Ilona Bárány-Kevei: A rewiew of the forest management history and present state of the Haragistya karst plateau (Aggtelek Karst, Hungary

The potential vegetation of Hungarian karsts is mainly mixed deciduous forest; consequently forest management is a key issue in the sustainable management of our karsts. In this study we attempt to describe on the example of the Haragistya karst plateau how the forests of the Aggtelek karst region were used in the last few centuries and to what extent they were affected by anthropogenic activity. Investigating change patterns in the context of land use history provides useful information for future management. For the analysis we used an integrated GIS of historical data (18th-19th century military maps, old forest management plans, aerial imagery etc.). Our study area, the Haragistya, is situated in the northern part of Aggtelek Mountains at 400-600 $\mathrm{m}$ above sea level. The forests of this karst plateau have been subject to significant human impact over the centuries. Anthropogenic influence gradually decreased over the 20th century and with the area being taken into state management the irregular and often exaggerated use has stopped. Keywords: forest management, Aggtelek Karst, forest history, Haragistya.
\end{abstract}

Izvleček

UDK 551.44:630^6(439)

Eszter Tanács, Ferenc Szmorad, Ilona Bárány-Kevei: Pregled upravljanja z gozdovi na planoti Haragistya (Aggteleški kras, Madžarska)

Vegetacijo Madžarskega krasa v glavnem sestavljajo listnati mešani gozdovi, zato je upravljanje $\mathrm{z}$ gozdovi ena glavnih tem trajnostnega upravljanja $\mathrm{s}$ krasom. $\mathrm{V}$ tej študiji, na primeru kraške planote Haragistya, prikažemo rabo gozdnih površin na območju Aggteleškega krasa v zadnjih stoletjih in obseg posledic človekovega vpliva. Raziskave speminjanja pokrajine $\mathrm{v}$ luči zgodovine rabe tal nudijo uporabne informacije za upravljanje v prihodnosti. Za analizo smo uporabili integriran GIS zgodovinskih podatkov (vojaške karte iz 18. in 19. stoletja, stari načrti upravljanja z gozdovi, aerofoto posnetke itd.). Študijsko območje Haragistya leži na severnem delu Aggteleških gora, na nadmorski višini $400-600 \mathrm{~m}$. Gozdovi tega območja so že dolgo izpostavljeni človeškemu vplivu. Ta se je manjšal v začetku 20. soletja, odkar je območje pod upravo države, pa je nepravilna in pretirana raba gozdov ustavljena.

Ključne besede: upravljanje z gozdovi, Aggteleški kras, zgodovina gozdov, Haragistya.

\section{INTRODUCTION}

Due to their geographical position the natural vegetation in Hungarian karstlands is mainly mixed deciduous forest and in our karst mountains there is still considerable forest cover. If forest management is carried out in accordance with the interests of protection and tourism, it can serve as a basis of sustainable landuse in these areas. Silvicultural activity also has an impact on the whole karstecosystem through changing the forest and the site. It defines the state and extension of a forest for centuries.

\footnotetext{
${ }^{1}$ University of Szeged, Department of Climatology and Landscape Ecology, Hungary; nadragulya@geo.u-szeged.hu ${ }^{2}$ Directorate of Aggtelek National Park, Hungary; info.anp@t-online.hu

${ }^{3}$ University of Szeged, Department of Climatology and Landscape Ecology, Hungary; keveibar@earth.geo.u-szeged.hu Received/Prejeto: 18.09.2006
} 
Forest management is therefore a key issue in the sustainable management of our karsts.

The present forest condition in Europe is considerably modified from the natural state (Bradshaw 2004). As a result, the natural dynamics of European deciduous forests are little known, which makes successful management difficult. In order to find out more about these processes forest reserves were designated where management activities were stopped entirely. Yet to understand changes that follow the abandonment of a forest we first need to thoroughly examine the history of forest management.

The specialty of karst areas (especially open karsts) regarding forest management is their high vulnerability. The forestry services of countries with larger consistent
Besides the pollution issues of increasing importance forest management in Hungarian karst areas had to face special challenges throughout its history. The most important of these are the shallow karst soils characterised by an extreme water balance, which affects species composition and quality. Through the ages this had an ambiguous effect on the forest management practices in Hungary's karst areas. The forests with the most extreme conditions (e.g. the steep southern slopes in the Aggtelek region) got legal protection very early in the interests of erosion protection and were usually not managed. Conscious management strategies favouring the sustainability of both wood supply and forest environment were only applied in a few privately owned big estates, which mostly encompassed high-quality forests. However most karstic forests did not belong in either category and were therefore exploited in many ways. The numerous uses these forests were continuously subject to have changed their structure and in many cases led to degradation.

Our study area, the Haragistya karst plateau, is situated in the Aggtelek Karst (in the southern part of the Gömör-Torna Karst), mainly in the strictly protected "A" zone of Aggtelek National Park (Fig.1) This plateau, similarly to other Hungarian karst areas, has been intensively used over the centuries so investigating its patterns in the context of land use history may provide useful karst areas are well aware of this therefore several attempts have been made to work out guidelines regarding forest management activities in such areas (e.g. Karst management handbook for British Columbia 2003). information for the future management of karsts. As the first step, this study summarizes the forest management history of the Haragistya plateau

\section{MATERIALS AND METHODS}

The study area was defined considering the available historical sources; we research the forests formerly belonging to Szádvárborsa village (today called Silická Brezová) and now to Aggtelek village. Most of these forests became part of the Haragistya-Lófej Forest Reserve in 1993. The Haragistya is part of the Silicka karst plateau, which mainly belongs to Slovakia. Its height above sea level var- ies between 400-600 meters. The bedrock mainly consists of Triassic limestone (Wetterstein Formation), dolomite and dolomitic limestone. The surface of the karst plateau is highly varied, especially the surface of the dolomite (Fig.2) In the east dry valleys can be found with a main $\mathrm{N}-\mathrm{S}$ direction while in the northern and western parts series of dolines dominate the surface. The vegetation 
mainly consists of sessile oak-hornbeam forests, with dry oak forests on the ridges and beech stands in the hollows and deeper valleys. There are also a few meadows and non-native coniferous plantations. Most of the forests originate from the period between the two world wars but the proportion of forests originating from the beginning of the $20^{\text {th }}$ century (1906-1926) is also significant.

We collected and integrated the available historical data of the area into a GIS. It includes some military maps of the Habsburg Empire (called Austrian-Hungarian Monarchy from 1867) made in 2 periods, namely between 1763-87 and 1819-1869, which are the oldest sources of spatial information of this area. Apart from defining the spatial extension of the forest at a certain time, these historical maps mostly provide indirect information by showing the location of important buildings (forester's house, roads etc.) or old geographical names that might be a hint of the characteristic activities of that age.

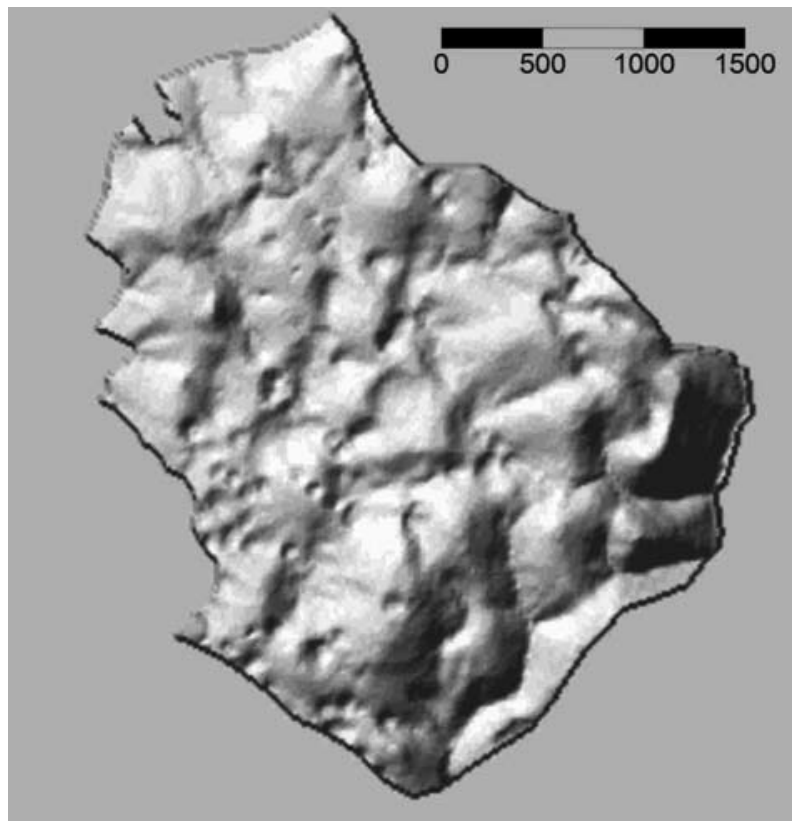

Fig. 2: The elevation of the study area.

Forest management plans and the attached maps are the most important data sources concerning a forested area. The archive plans were provided by the Miskolc Directorate of the State Forestry Service with the permission of Északerdő Forestry Co., the present forest manager of the area. The first management plan of the Haragistya dates back to 1934 . The attached map holds lots of geographical names besides the boundaries of the forest sections. The temporary plan made in 1944 and the first one made after the 2nd World war are missing. The first document available from after the war dates back to 1961 and it is followed by plans prepared every ten years in 1973, 1983 and 1993.
In the interests of conservation we took photos of the archive plans and the attached maps instead of scanning. The data were integrated in Excel 2003 tables while the maps were georeferenced with the help of ERDAS Imagine 8.6 software. First we used polynomial transformation but the RMS error was about 30-40 meters in most cases because of the strong distortion. Since the section boundaries are often defined according to the elevation (along valleys or ridges) or existing routes and the occasional modifications usually happen by the union or division of the already existing sections we finally decided on using the rubbersheet method instead. The forestry maps were fitted to each other using hundreds of GCPs, mainly the breakpoints of the section boundaries. The maps were then digitised and the forestry database joined to them in ArcView GIS 3.3 software. For control the section area data in the database were compared with the area of the corresponding ArcView polygons. The average difference is about $0.26-0.3$ hectares.

Besides the data referring to the basic characteristics of a forest (production site characteristics, species composition, average height, average dbh - diameter at breast height -, etc.), forest management plans also contain a record of the work performed in the given period. In some cases they include historical descriptions and the critics of earlier management as well. The content of the plans made in different periods is not uniform, the recording methods can only be considered standardized after 1973. The unit of forest management is the forest section, of which the boundary (and consequently the size) can change from time to time because the boundaries are defined according to the production site characteristics and the performed works. The data apply to the sections and thus changing the boundaries makes temporal analysis rather complicated. This practice also means information loss in the case of a highly varied surface (like that of a karst plateau) because the spatial variability of the surface is higher than the resolution of the available data.

By the union of the maps from the different planning periods we got polygons representing areas with a uniform management history. In the period between 1973 and 1993 most section boundaries were unchanged so changes in the species composition can be quantitatively analysed. Yet data interpretation should be carried out carefully with regard to the fact that the introduction of a new species in the range of the recorded species (eg. Quercus pubescens or Larix decidua) can significantly modify the data without any major change occurring in the examined period.

Archive aerial imagery can provide useful complementary information. The oldest photos of the area date back to 1952 and were made available by the Directorate of Aggtelek National Park. 


\section{RESULTS AND DISCUSSION}

\section{THE AGE OF IRREGULAR FOREST USE}

Before the $16^{\text {th }}$ century forest use was generally haphazard, wood production was carried out irregularly and only in small areas at the same time. People used the forest resources but didn't need to consider regeneration and sustainability. From the $16^{\text {th }}$ century on wood was used in new ways and production became regular. A special product of karst regions affecting forest use was lime, made in pit kilns. In the Gömör-Torna karst area clearcuttings were carried out in large areas in order to satisfy the charcoal claim of the furnaces in the nearby Sajó valley. Meanwhile grazing, a common practice at that age, prevented the natural regeneration by seedlings. Forest was not as valuable as arable land or vineyards so wherever possible it was replaced with other forms of agricultural landuse. In the remaining forests species composition changed in favour of less seeked-out species with a better ability to tolerate disturbance and grazing, especially hornbeam (Carpinus betulus). The impact of grazing was recognised as early as the $16^{\text {th }}$ century but despite continuous banning it was a characteristic way of forest use in the area until the $20^{\text {th }}$ century (Járási 1997). In order to cover the need for timber and to help natural regeneration some older and larger trees were sparsely left standing as seed trees. This is the so-called 'composite forest', which consists of younger coppice stands with a few older trees originating from seedlings. It was a common form of forest management in the karst area until the $20^{\text {th }}$ century (Járási 1998). Some of the seed trees can still be found in the older forests.

The early history of the Haragistya area is similar to the whole of the Gömör-Torna karst region. In the Middle Ages it formed part of the Szádvár estate, which, according to the custom of the age, often changed its owners but most of the proprietors were private individuals until 1934 (Járási 1997, 1998). The earliest available map was prepared during the first military mapping of the Habsburg Empire (1763-87). Nagy (2003) has processed the material of the military mappings concerning the whole area of the Aggtelek National Park. The landuse map of the 1780 's, prepared by him, shows that the Haragistya area was partly used as forest, arable land or dry meadows, but mostly as pasture. The military descriptions attached to the maps describe the Szádvárborsa forests as sparse and bushy, which supports the evidence of the maps. It is also mentioned that oak (probably sessile oak) and beech dominated these forests at the time. The memories of common landuse at that time live on in the geographical names found on topographical maps and on the forestry map of 1934: 'Cabbage-peak', 'Ewe-hollow', 'Shepherd- valley', etc. The traces of strongly eroded agro-terraces in some parts of the plateau can also be considered a sign of former arable farming along with the very shallow (5-10 $\mathrm{cm}$ ) soils of ridges and tops, which hold clearings where reforestation is very slow.

\section{THE MANAGEMENT IN THE $19^{\text {th }}$ CENTURY}

In the beginning of the $19^{\text {th }}$ century the question of the sustainability of forests in Hungary has already arisen and a forestry law was brought in for their protection (no. XXI in 1807). But by that time forests had become the main and most reliable profit sources of their owners and consequently the provinces who had the executive power were not eager to act in the interests of protection. Due to that and some legal loopholes the law didn't have much effect. With the construction of new railways clearcuttings started in remote areas where large-scale wood production had not been profitable before.

According to the map of Nagy (2003) that describes the area's landuse in the 1850's (based on maps of the second military mapping between 1819-1869), reforestation on the Haragistya plateau has started or intensified by that time. This is opposite to the general tendency of deforestation at the time explained by the increasing value of the forest in relation to other ways of landuse. Apart from a few clearings there has been continuous forest cover on the plateau ever since. In the 1870 's the furnaces in the Sajó valley switched to the use of coal but the claim for a new product, the tanning bark intensified the unfavourable tendencies in the area's management policy. The harvest cycle of sessile oak forests was reduced to 15-20 years and they were renewed by means of sprouting. These coppice stands were gradually degraded and in time hornbeam took their place (Járási 1998). Coppicing generally resulted in a decrease of genetic diversity, even in the case of species with a good sprouting ability. The state and wood quality of sprouted individuals or those cut down several times is usually worse than those of trees originating from seeds and often their production rates are lower as well (Bartha 2001). Hornbeam dominating the forests may have been unfavourable from the wood production point of view but the dense juvenile stands of hornbeam prevented soil erosion and thus in many cases the utter disappearance of the forest (Gencsi, Vancsura 1992). The high proportion of coppice forests and hornbeam in the study area in 1934 suggests that the forests of the Haragistya plateau were not an exception either.

Because of the general degradation of the native forests, in the end of the $19^{\text {th }}$ century coniferous forests were planted in many places; in the Aggtelek karst region as 
well. In the area black pine (Pinus nigra) and Scots pine (Pinus sylvestris) were preferred especially in protective forests (of which the primary role was to prevent soil erosion). These tries usually proved a failure in the long run (Járási 1997). According to the plan of 1934 the Pinus nigra forests of the Haragistya, probably planted at the beginning of the century, were only present in two sections.

\section{FORESTS ON THE EDGE}

By the beginning of the $20^{\text {th }}$ century the principles of sustainable forest management were worked out in Hungary but neither the economic environment nor the property structure were favourable. The forestry law of 1879 didn't properly regulate private forest use even though it clearly defined protective forests and introduced the compulsory use of management plans in the case of state-owned forests (Járási 1997). Information on the state of the Haragistya forests at the beginning of the $20^{\text {th }}$ century can be deduced on the basis of the management plan of 1934 and of certain characteristics of the present age distribution and species composition. Most of the trees originate from coppice stools, which shows that after the last harvest cuttings the stands have not been professionally renewed; the present forests regenerated due to mainly spontaneous processes (sprouting). Traces of charcoal burning and the former lime kilns can still be found in the valleys. These activities resulted in the appearance of pioneer species in the hollows, like birch (Betula pendula) and trembling aspen (Populus tremula), both preferring acidic soils. Birch, being a short-lived tree, is about to disappear from the area; a few can still be found standing but more often it can be seen in the form of deadwood.

The wars and the economic crisis in the first half of the $20^{\text {th }}$ century increased the need for timber and made it impossible to bring in proper legislation or even enforce the existing laws. According to the peace treaty of Trianon in 1920 Hungary lost two-third of its original area and most of its forests. This had a subtle but important long-term effect on the Haragistya since it resulted in the plateau becoming a peripheral area. Its characteristic triangle-shaped road network can already be discovered on the military maps. The fork of the two main roads to Szilice (in the north-east) and Szádvárborsa (in the northwest) was situated in the southern part of the area. Since the Trianon treaty both settlements have belonged to Slovakia, therefore the plateau has become a peripheral area and the roads that had been used daily before have been gradually degraded to forestry access roads. This may have contributed to the gradual decrease of anthropogenic impact in the $20^{\text {th }}$ century.
The increasing demand for wood after the 1st World War meant an increasing pressure on the remaining forests, especially that during the economical crisis most forest owners had no other income. Productions exceeding the plans were more easily allowed because of the wood shortage and because the state hoped for more tax income (Járási 1997). The result of these tendencies is still mirrored in the age distribution of the forests in the Aggtelek area.

In 1934 the estate where the Haragistya belonged was bought by the Treasury and became part of the Szin management unit (Járási 1997, 1998). The first management plan covering our study area was made at that time. The age data of this plan are contradictory as many of the sections have two data; besides the ones in the tables' records there are some scribbled pencil notes which show rather higher values. We assume that these notes show the ages of some remnants of older forests, which were cut down during the following war. Yet most forests were only a few years old at the time, especially in the southern area, which is closest to the nearest settlements. The species composition data only hold information on a few species (Fig. 3a); according to this the forest mainly consisted of sessile oak (Quercus petraea) and hornbeam (Carpinus betulus) with trembling aspen (Populus tremula) in some places and with beech (Fagus sylvatica) in the southeast. (When comparing the distribution of beech in the year 1934 to the military descriptions, it is surprising to see how the role of this species diminished over the two centuries). Some other species are included in the footnotes, for example wild service (Sorbus torminalis) seed trees are mentioned in several cases. In some sections in the northwest black pine (Pinus nigra) was also present, probably as the result of earlier plantation works.

Wood production at that time was mainly concentrated to the western and northern parts of the area and in most cases it meant clear-cutting. The increasing wood claim of the war preparations can be clearly seen in the increasing tendency of the production data of the Haragistya area from 1939 (Fig. 4) The fact that the cities of Kassa and Rozsnyó were returned to Hungary in 1938 without their forests (due to the First Vienna Arbitration Award) probably also played a role in this; the remaining areas had to cover the increased wood claims (Járási 1998). In 1942 and 1943 there were no production works in the Haragistya area, probably due to the increasing intensity of war activities and the following lack of labour. The data of the works carried out in 1944 are but pencilscribbled notes on sheets; the wood was used for satisfying local needs (that of the school, the village judge, etc.). The share of the forest manager signing the plan was also provided from the Haragistya forests. The temporary plan made in 1944 and the first one made after the $2^{\text {nd }}$ 


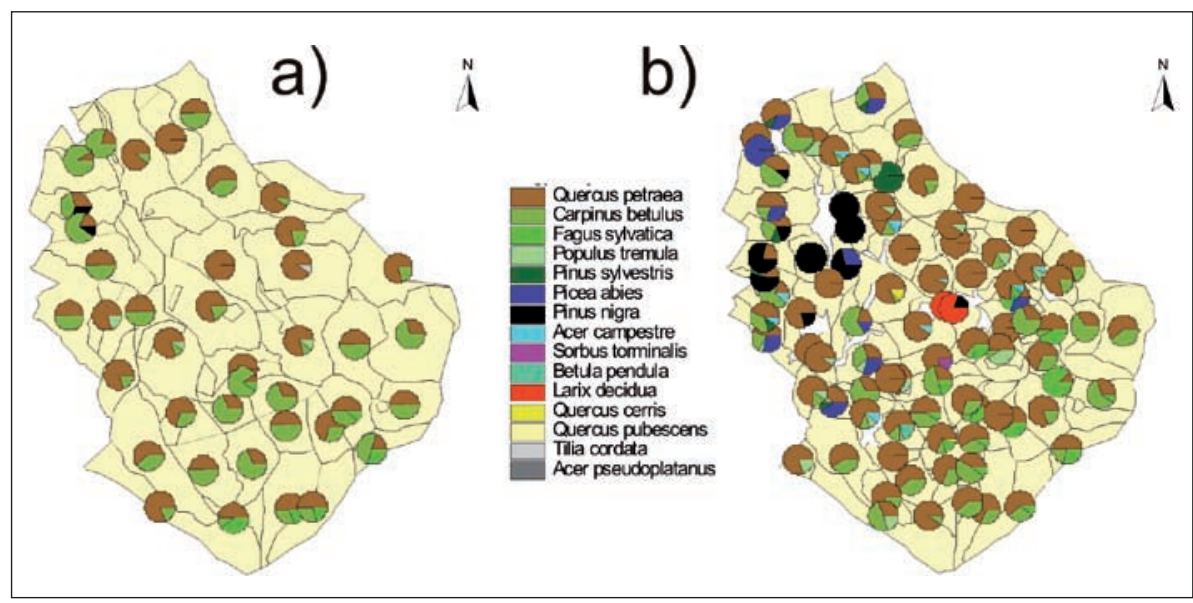

Fig. 3: Species composition in a) 1934 b) 1961.

World war in the beginning of the 1950's are missing so there are no data available from the reconstruction period. Yet it is known that by the end of the II World War and the reconstruction there were almost no forests left suitable for production in the Aggtelek area. Often there were no proper financial sources for renewal and even if it was successful, it was usually based on sprouting (Járási 1997, 1998).

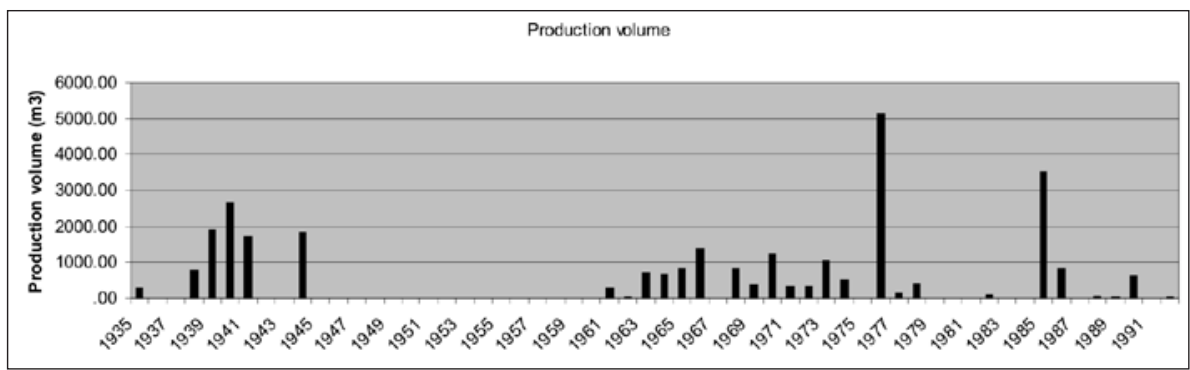

Fig. 4: The yearly volume of wood production 1935-1992.

\section{THE STATE OF FORESTS AFTER THE II. WORLD WAR}

After the war the most important tasks of forestry were to make up for the unfinished regeneration works, to plant fast-growing species (conifers, etc.) and to convert the degraded coppice forests (often by replacing them with non-native coniferous plantations). Accordingly in the years after the war there were almost no production works, forestry concentrated on renewal. Changes in the property structure after the war were favourable for long-term planning: during the agrarian reform in 1945 all forest areas larger than approx. 142 acres were taken into state management. This made it possible to apply the principles of sustainable management and to correct earlier mistakes (Járási 1997). From the 1950s regular man- agement, based on a professional background, gradually took over. This practically determined the fate of the forests in the Aggtelek karst region until the area was placed under protection.

Despite the missing data, aerial photos from 1952 and 1956 provide some information on the state of the Haragistya forests in this period (Fig. 5) These show open, grove-like forests in much of the area, which, as it can be seen on the aerial photo from 1997, have almost entirely closed in (probably due to the declination of grazing). This is confirmed by the presence of dead juniper (Juniperus communis) in almost every forest type, which is the sign of the formerly more open vegetation. On the slowly reforesting clearings of the southern slopes there are still a few withering junipers, while under the beech stands of the valleys the remnants of individuals withered decades ago sign the closure of the vegetation.

According to the stories of the inhabitants of Jósvafö (the nearest village), the forester's house situated in the north-western part of the plateau was still inhabited at the time and the farm was flourishing. Livestock was grazed in the clearings around the house, which prevented reforestation (today the national park keeps up some of those clearings by mowing). In the vicinity of the forester's house there was also rather more intensive management activity than in the remote parts of the plateau.

A lot can also be learnt about the post-war works from the management plan made in 1961. There was evidently a significant modification of the section boundaries compared to 1934. More and smaller sections were formed, probably in order to adapt them to the characteristics of the forest stands and the production sites. This plan also holds information on more species than the 1934 one (Fig. 3b).

In the northern and north-western part of the area coniferous plantations (mainly Scots pine, spruce and in a few places black pine) appear on the species composition map of 1961 in the place of native forests cut down 

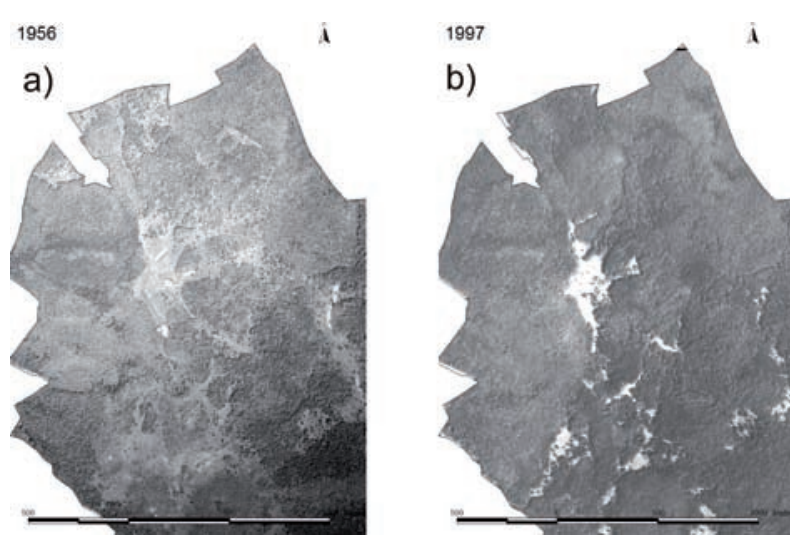

Fig. 5: Aerial photos of the northern part of the Haragistya plateau a) 1956 b) 1997.

earlier. Because of the wood claim of the post-war reconstruction typical management at the time included the plantation of fast-growing non-native conifers. Forest managers aimed to utilise the poor-quality karstic sites by introducing these species. Increasing the proportion of conifers in the Aggtelek area was a proclaimed aim of management even in the 1970's although the last Picea abies plantation (started in 1964) on the Haragistya plateau was finished at that time.

It is important to note the relatively high number of sections (10) where the stands are shown to have consisted entirely of sessile oak. The average size of these sections $(7.74 \mathrm{ha})$ shows that these were not all smaller stands. The management plan of 1973 emphasized the need to suppress hornbeam in favour of sessile oak; this endeavour has probably been present in forest management already before and they tried to suppress hornbeam by carrying out stand treatment in favour of the sessile oak. Beech appears in an apparently larger area than in 1934. Besides species selection carried out in favour of this species, the modification of the section boundaries could have also played a role in this since beech in this area can usually be found in small patches in the valleys and on northern slopes and its proportion was probably only a fraction in the large sections. By 1961 beech also appeared in sections where it had not yet been present in 1934 (although only in the southwest).

Wood production in the 1960's was not significant as it mainly came from thinning works rather than clearcutting (Fig.6) Sessile oak provided the highest volume, followed by hornbeam and beech. The young conifers were sold for Christmas trees.

\section{THE LAST ACTIVE PERIOD OF MANAGEMENT}

In 1978 the Aggtelek Landscape Protection Area was formed in the karst area and in 1979 a small part of the plateau (compartment 20) was also designated UNESCO MAB Biosphere Reserve. Yet in the management plan of 1973 most of the Haragistya is already labelled "protected" or "strictly protected" as the surface protection zone of the nearby Vass Imre cave. Besides an effort to simplify data management this might have been the cause of another significant change in the average size of the forest sections, which increased from 7.72 ha to $11.23 \mathrm{ha}$ ). As a result, the species composition of the sections seemingly became more diverse (Fig. 7a). The spreading of spruce continued according to plan in the period between 1961 and 1973 and by 1973 the coniferous plantations have appeared in most sections in the north-western half of the area. The conifers were mostly planted together with native species, pure spruce stands can only be found in very small $(0,2-0,3 \mathrm{ha})$ sections. The proportion of conifers was usually increased at the expense of sessile oak stands. In the south-eastern part of the plateau sessile oak, hornbeam and beech were dominant, along with trembling aspen in certain places. The proportion of beech apparently increased in this period. Downy oak (Quercus pubescens) appears in the dataset for the first time in 1973 in a few sections in the east. It had surely been there even before but since it doesn't play an important role in wood production it was probably ignored.

After 1973 there were only lesser modifications of the section boundaries so in the case of the unchanged sections it is possible to

Fig. 6: The yearly volume of wood production by species 1961-1972. 


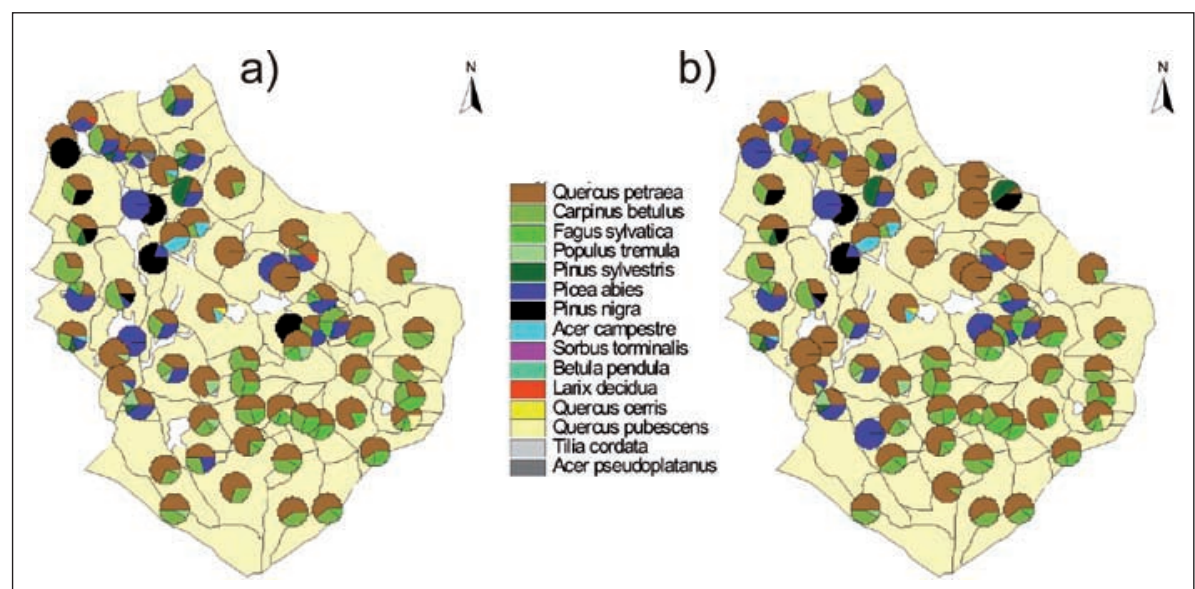

Fig. 7: Species composition in a) 1973 b) 1983.

quantify changes in the species composition. We concentrated on the data of sessile oak, hornbeam and beech since these are the dominant native species of the area and the future changes in their proportions are of great importance.

In the period between 1973-1982 wood production still mainly came from thinning works. In 1976 increment thinning was carried out in a few sections; the trees removed were mostly sessile oak and hornbeam (Fig. 8). There were only lesser changes in the species composi-

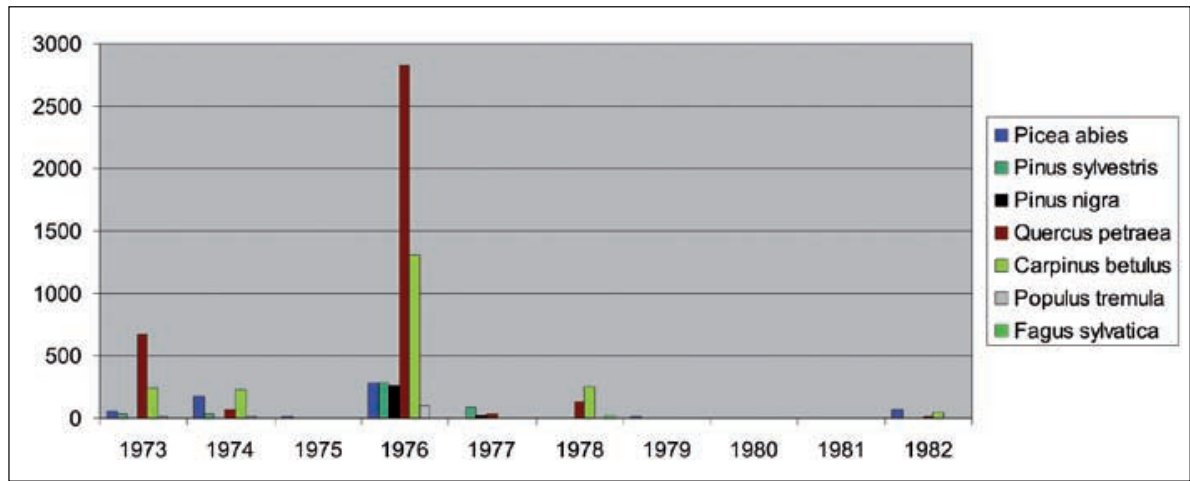

Fig. 8: The yearly volume of wood production by species 1973-1982.

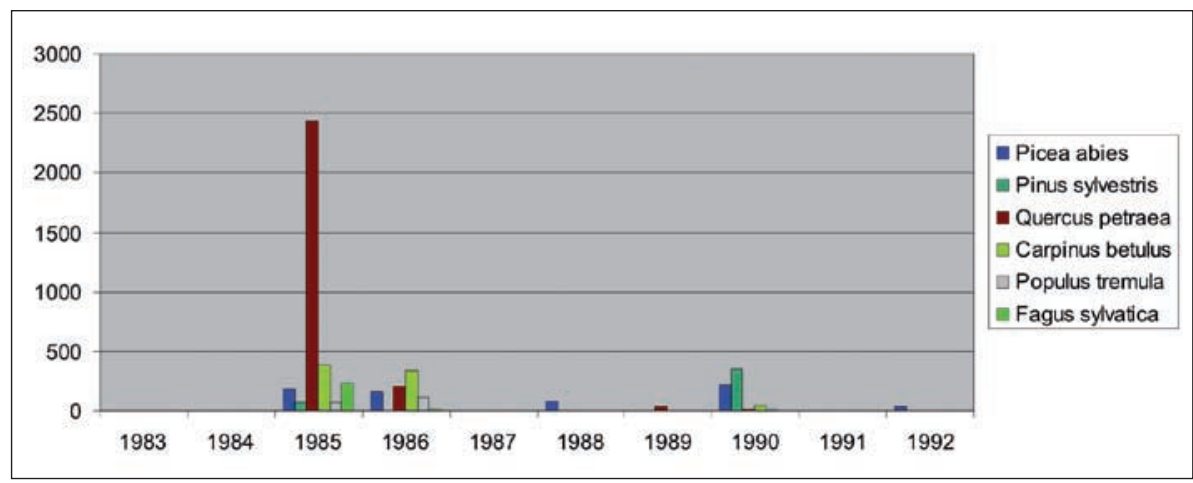

Fig. 9: The yearly volume of wood production by species 1983-1992. tion at the time (Fig. 7b). The proportion of sessile oak in this period slightly increased in a few sections (mainly due to the removal of other species) while that of hornbeam slightly decreased. Changes in the two species' proportion usually have opposite tendencies. The spreading of hornbeam usually results in the withdrawal of oak while forest management practices usually aim to suppress hornbeam and aid the spreading of oak. The proportion of beech in this period only changed in 3 sections; it increased in all 3 cases, due to management works.

In the period between 1983 and 1992 some major changes occurred. By the 1990's other functions of the forests were increasingly accepted and besides the economic interests forest management concentrated more and more on other aspects, like conservation and tourism. On 1st January 1985 the Haragistya area became part of the newly declared Aggtelek National Park. Although some large-volume increment thinnings took place in 1985 and 1986 final cuttings were still not carried out. After 1986 major wood production works only continued in the coniferous forests, due to restrictions from the conservation authorities (Fig. 9).

In most of the area the proportion of sessile oak decreased in this period while there was a significant increase in the proportion of hornbeam at the same time (Fig. 10). These changes are complementary in most sections (Fig. 11) except those where beech started to spread. Since during the thinning works the wood produced mainly consisted of sessile oak, the decrease in its proportion is not surprising; although it is interesting that the attempts to suppress 


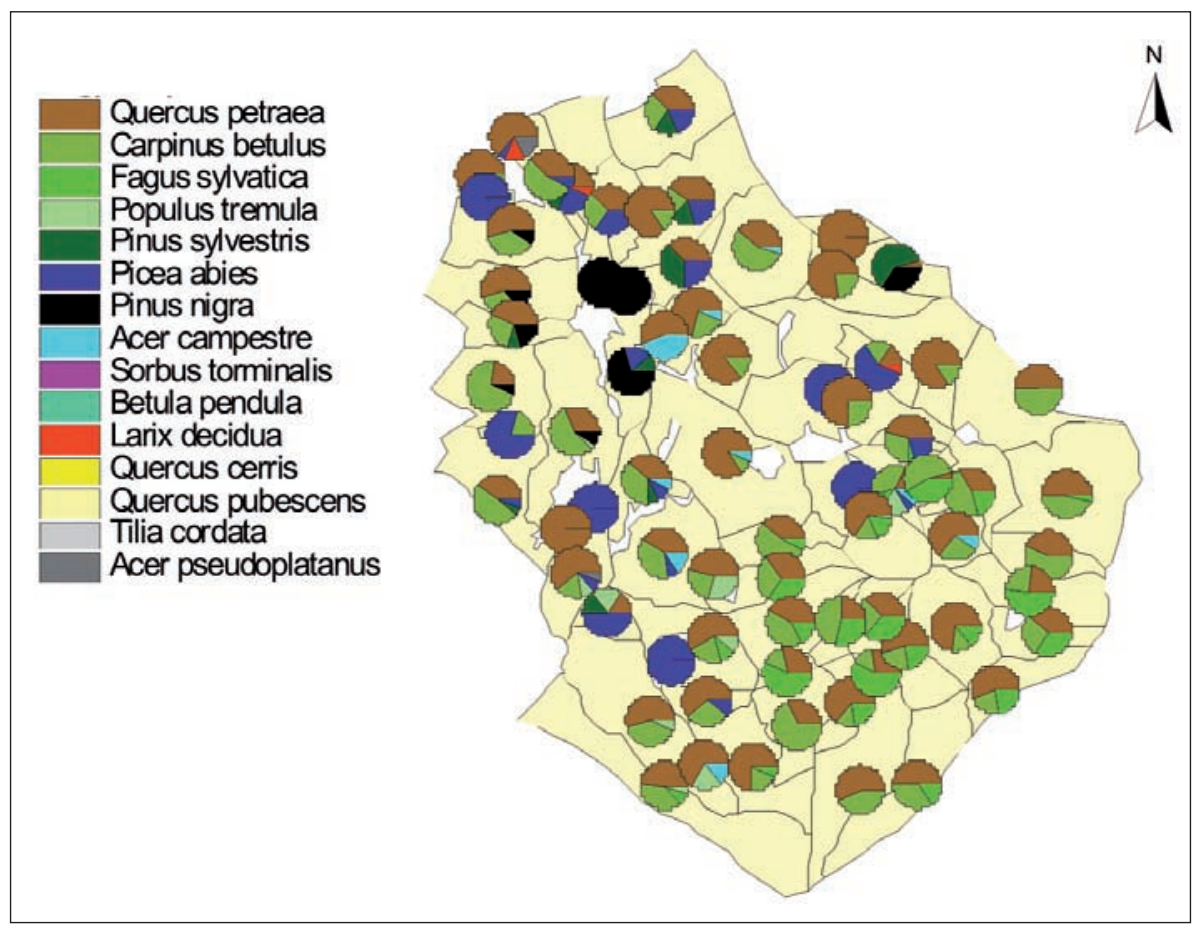

Fig. 10: Species composition in 1993.

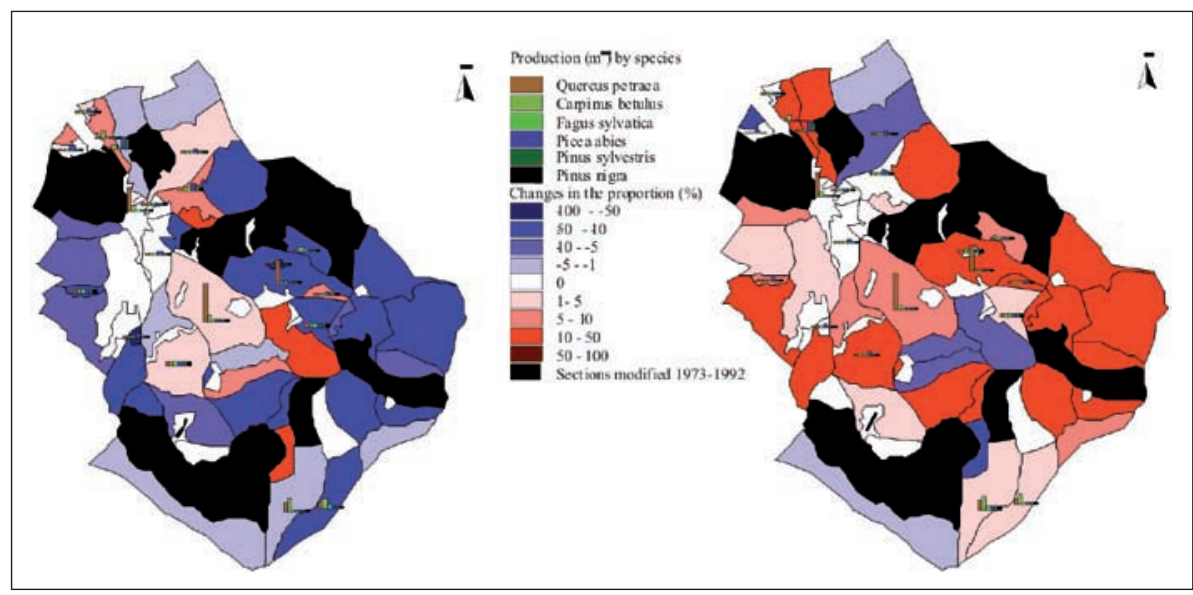

Fig. 11: Changes in the proportion of a) sessile oak b) hornbeam between 1983-1992.

ment activity ceased in the core areas of the reserve. The directorate of the national park still permitted production in the coniferous forests and some thinning works in the buffer zone.

\section{CHANGES IN THE AREAS OCCUPIED BY THE DIFFERENT TREE SPECIES FROM THE FIRST HALF OF THE $20^{\text {th }}$ CENTURY UNTIL 1993}

Besides overviewing the experiences of the different historical periods examining the areal changes of the tree species over the 6 decades of which the data are available brought interesting results and new questions.

In the study area sessile oak has been dominant over the whole period; from 1934 its area has been slightly decreasing (Fig.12.) despite the fact that in these 60 years there were no final cuttings in any oak stands. The loss of area may be explained by thinnings carried out at the expense of the oak stands although management should have served the spreading of this species. The best example of unprofessional concentrated thinnings are the production works carried out in 1985 (nearly $2500 \mathrm{~m}^{3}$ of ses-

hornbeam ceased. Nevertheless the tendency is also present in sections where production works were not carried out at the time. The proportion of beech mainly increased in areas with western aspect.

The description of thinning works carried out in spruce forests in this period often contains the note "cut down for health reasons", which shows that these stands are not too stable. According to the health data in the management plan of 1993, most of the damaged stands $(10-50 \%$ of the whole section area) contained conifers.

In 1993 the south-eastern part of the area was designated forest reserve and consequently all forest manage- sile oak was cut down); the impact of these will probably influence the look of the involved stands for decades.

The other significant species characteristic of the area is hornbeam, which appears as the rival of sessile oak. The high proportion of hornbeam in the young stands of the 1930's was, over time, partly reduced by the artificial plantation of conifers (spruce, Scots pine and black pine) and to a lesser extent by the spontaneous spreading of beech. After that the area of this species stagnated for 3040 years (Fig.13.). From the 1980's the area of hornbeam has started to increase again, mainly because of the thinnings that resulted in the suppressing of sessile oak. 


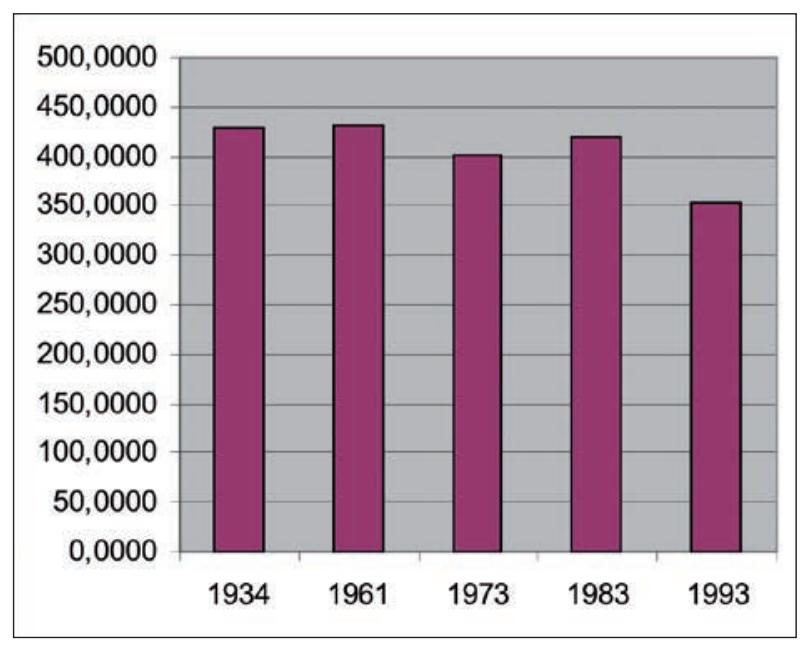

Fig. 12: The area (ha) occupied by sessile oak (Quercus petraea).

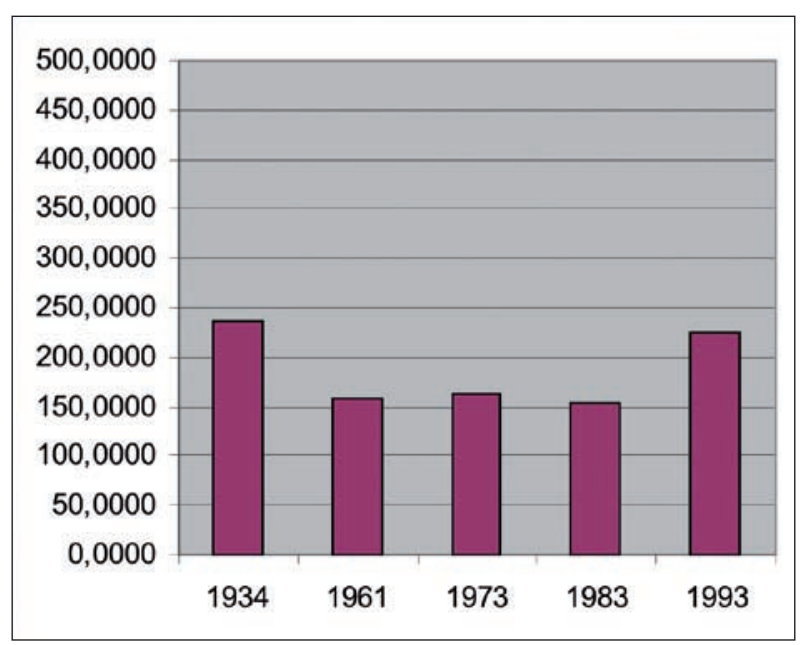

Fig. 13: The area (ha) occupied by hornbeam (Carpinus betulus).

Beech shows a slow but constant increase of area over the examined period (Fig. 14.). The reason for this is probably the fact that it was strongly suppressed in the past. This species, now occupying a fraction of its original area, is slowly conquering its former sites again.

Finally it is important to mention the non-native coniferous species that were planted on the plateau. Their proportion in the 1930's was insignificant; black

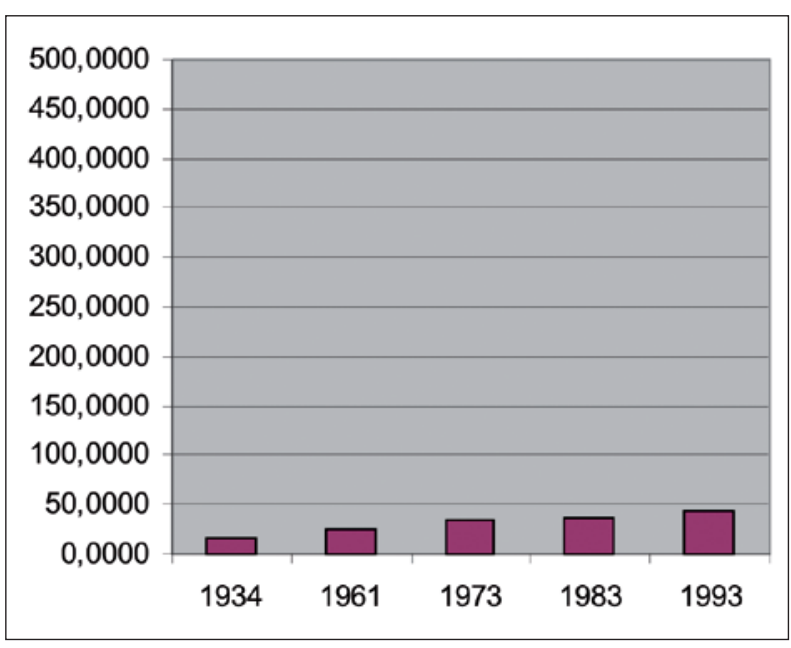

Fig.14: The area (ha) occupied by beech (Fagus sylvatica)

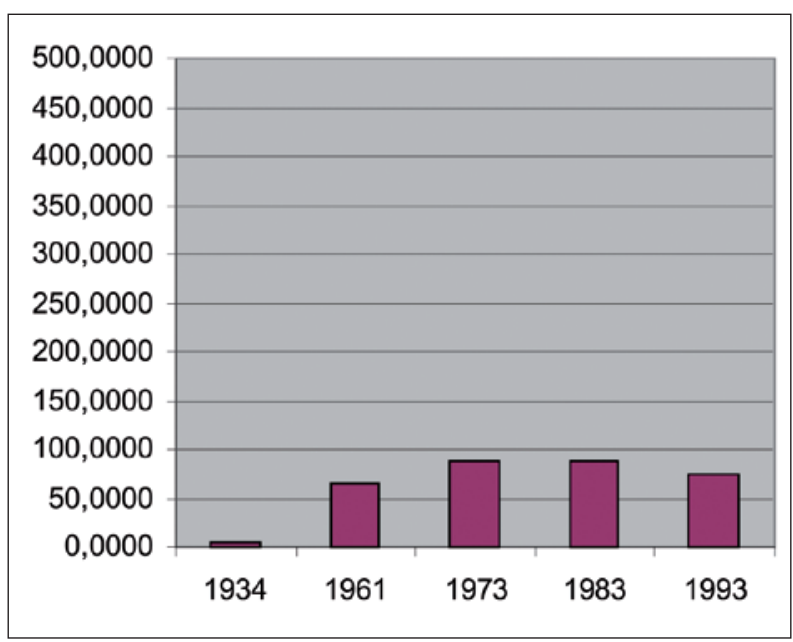

Fig. 15: The area (ha) occupied by conifers (Picea abies, Pinus sylvestris, Pinus nigra).

pine was present in only two sections. Due to the campaign-like planting of conifers after the II. World War their area grew fast. In the 1970's they already covered $10 \%$ of the study area (Fig. 15). Later, due to the lack of space, this increase has stopped while these days it is nature conservation that put an end to the spreading of these species.

\section{CONCLUSION}

The forests of the Haragistya plateau (situated in the Aggtelek karst region) serve as a good example of karstic forest management in Hungary. They have been subject to significant human impact over the centuries. After the area being used partly as agricultural land, forest cover has been continuous on the plateau since the beginning of the 19th century. Traces of the exaggerated use (extreme production rates, coppicing and other forest uses) 
characteristic at the end of the 19th and the beginning of the 20th century can still be discovered in today's species composition and stand structure. Human impact gradually decreased over the 20th century and with the area being taken into state management the irregular and often exaggerated use has stopped. In the middle of the century coniferous species were planted on the karst plateau in the interests of a more intensive utilisation, as was the case in a lot of other karst areas. The volume of wood production has shown a gradually decreasing tendency from the 1960's; at first there was a lack of forests suitable for production while production works were limited when the area was placed under protection. The proportion of sessile oak and hornbeam dominating the plateau in the first half of the 20th century gradually decreased, partly due to the coniferous plantations in the north, partly because of the spontaneous spreading of beech in the southeast. Finally the realisation of the importance of karst surface protection led to these forests being placed under protection. Thus the proportion of old stands (more than 80 years old) on the plateau is higher than the national average. The relatively slow growth of these forests, due to earlier coppicing and the shallow karstic soils also played a major role in this.

\section{ACKNOWLEDGMENT}

The research was funded by the Hungarian Scientific Research Fund (OTKA/T048356). The authors express their thanks to the Északerdő Forestry Company for their permission to use the data, to Sándor Bényei, deputy direc- tor of The Miskolc Directorate of the Forestry Service for his help and to Zoltán Szabados, geography student at the University of Szeged, for his work!

\section{REFERENCES}

Bartha D. 2001: Veszélyeztetett erdőtársulások Magyarországon (Endangered forest associations in Hungary).- WWF füzetek, 18, WWF Magyarország, Budapest (http://www.wwf.hu/wwffuzetek.php)

Bradshaw R. H. W. 2004: Past anthropogenic influence on European forests and some possible genetic consequences. Forest Ecology and Management 197 (2004) 203-212

Gencsi L.,Vancsura R. 1992: Erdészeti növénytan II. (Dendrológia - Dendrology).- Mezőgazda Kiadó, Budapest.

Járási L. 1997: Erdőgazdálkodás Bánkúttól Nagy-Milicig (Forest management from Bánkút to Nagy-Milic).Északerdő Rt., Miskolc.

Járási L. 1998: Az erdőgazdálkodás múltja (The past of forestry in Aggtelek National Park). In: Baross G. (szerk.): Az Aggteleki Nemzeti Park. - Mezőgazda Kiadó, Budapest, 395-410.

Karst management handbook for British Columbia. For. B.C. Min. For., Victoria, B.C. http://www.for.gov. bc.ca/hfp/fordev/karst/karstbmp.pdf
Keveiné Bárány I. 2004: A karsztökológiai rendszer szerkezete és müködése (The structure and functioning of the karstecosystem). - Karsztfejlödés (BDF Természetföldrajzi Tanszék, Szombathely), 9, 65-74.

Nagy D. 2003: Tájtörténeti kutatások a Gömör-Tornaikarszton I. A történelmi táj rekonstrukciója az ANP környezetében az I-III Katonai Felmérések alapján (Landscape history research in the Gömör-Torna karst area I. The reconstruction of the historical landscape in the vicinity of Aggtelek National Park on the basis of the I-III military maps). - ANP füzetek, 2, 107-143.

Temesi G. 2002 Az erdőrezervátumok fenntartásának általános irányelvei (General guidelines of forest reserve management). In: Horváth F., Borhidi A. (szerk.): A hazai erdőrezervátum-kutatás célja, stratégiái és módszerei. - TermészetBúvár Alapítvány Kiadó, Budapest, 38-45. 
